\title{
PENINGKATAN LITERASI KEUANGAN MELALUI PERENCANAAN KEUANGAN KELUARGA
}

\author{
Zul Azmi*, Della Hilia Anriva, Siti Rodiah, Wira Ramashar, \\ Muhammad Ahyaruddin, Agustiawan, Evi Marlina, Isran Bidin, Adriyanti \\ Agustina Putri, Nadia Fathurahmi Lawita \\ Prodi Akuntansi, Fakultas Ekonomi dan Bisnis \\ Universitas Universitas Muhammadiyah \\ email: zulazmi@umri.ac.id
}

\begin{abstract}
Training and counseling is also intended to provide practical education on financial planning, encouraging a shift in the tendency of consumptive behavior to be investative and increasing financial literacy. Based on the survey on financial planning management, it is found that the level of financial literacy in the vocational school community still needs socialization using financial planning on family life. Whereas if viewed from the average total income earned is sufficient at the regional minimum wage level and even above. This activity is done in the school environment of SMK at Kecamatan Dayun Siak District. Direct training and counseling approaches are used to interact directly with participants, discussion media and frequently asked questions to improve literacy. The results demonstrate the enthusiasm of the training by providing practical examples and discussions at the training and counseling sessions. Participants eagerly ask questions about these practical knowledge and expect there will be continuity of capacity building. Participants demonstrate an increased change in understanding of the priority scale of consumption behavior by prioritizing what is needed rather than desirable.
\end{abstract}

Keywords: financial literacy, family finance

\begin{abstract}
Abstrak
Pelatihan dan penyuluhan ini juga dimaksudkan untuk memberikan edukasi praktis mengenai perencanaan keuangan, mendorong pergeseran tendensi prilaku konsumtif menjadi investatif dan meningkatkan literasi keuangan. Berdasarkan survei mengenai pengelolaan perencanaan keuangan, diperoleh informasi bahwa tingkat literasi keuangan pada masyarakat sekolah SMK masih memerlukan sosialisasi menggunakan perencanaan keuangan pada kehidupan keluarga. Sedangkan jika ditinjau dari rata-rata penghasilan total yang diperoleh telah memadai pada level upah minimum regional dan bahkan diatasnya. Kegiatan ini dilakukan di lingkungan sekolah SMK pada Kecamatan Dayun Kabupaten Siak. Pendekatan pelatihan dan penyuluhan langsung digunakan untuk berinteraksi langsung pada peserta, media diskusi dan tanya jawab dilakukan untuk meningkatkan literasi. Hasilnya menunjukkan adanya antusiasme dalam pelatihan dengan menyediakan contoh-contoh praktis dan diskusi pada sesi pelatihan dan penyuluhan tersebut. Partisipan dengan semangat mengajukan pertanyaan tentang pengetahuan praktis tersebut dan mengharapkan akan ada kelanjutan capacity building. Partisipan menunjukkan perubahan peningkatan pemahaman tentang skala prioritas prilaku konsumsi dengan mendahulukan yang dibutuhkan daripada yang diinginkan.
\end{abstract}

Kata kunci: literasi keuangan, Keuangan keuarga 


\section{PENDAHULUAN}

Beberapa waktu yang lalu, masyarakat dikejutkan dengan naiknya harga bahan bakar minyak pertalite, langkanya bahan bakar minyak premium yang menjadi andalan masyarakat untuk beraktivitas. Demikian juga naiknya harga-harga barang umum membuat masyarakat tertentu harus berusaha ekstra dengan mencari alternatif sumber pendapatan lain yang mendukung keuangan rumah tangga menutupi biaya hidup seharihari. Akibatnya, seluruh individu anggota keluarga yang telah dapat diberdayakan dituntut untuk berusaha mendukung ekonomi keluarga. Setidaknya hal itulah yang dirasakan ada pada wilayah observasi. Menjadi kurang lazim pula, bila ibu rumah tangga yang berdiam dirumah sebagai ibu rumah tangga yang tidak produktif. Pada banyak kasus yang diamati, suatu keluarga kerap terperangkap dengan pemenuhan kebutuhan yang sesungguhnya merupakan keinginan yang dapat menjeratnya pada permasalahan ekonomi yang semakin kompleks.

Adanya penawaran kredit yang mudah diperoleh dari pihak-pihak tertentu dan program-program kemudahan serta diskon yang menggiurkan mendorong skala prioritas bergeser pada perencanaan konsumtif. Ujungnya, bukan tidak mungkin keluarga tersebut akan terlilit hutang. Kesulitan keuangan diketahui dapat berdampak pada prilaku menyimpang. Di sisi lain, apabila pemahaman mengenai perencanaan keuangan dan peningkatan literasi keuangan diperoleh lebih awal, diharapkan kondisi ini bisa diperbaiki dan justru dapat meningkatkan kesejahteraan ekonomi keluarga.

\section{Literasi Keuangan}

Literasi lebih dikaitkan dengan peningkatan kepemilikan pengetahuan dasar atau kompetensi. Edukasi pada masyarakat yang telah dilakukan meluas untuk berbagai bidang seperti pola sehat kehidupan remaja, kebiasaan hidup sehat, pemahaman dampak negatif narkoba dan miras, jauhi seks bebas, berantas buta aksara telah menjadi agenda nasional, dan tidak luput juga peningkatan pengetahuan pengelolaan keuangan telah dilakukan oleh pihak pemerintah dan swasta. Edukasi yang dilakukan lebih pada peningkatan literasi.

Kegiatan literasi pada bidang keuangan, dilakukan oleh Bank Indonesia, Otoritas Jasa Keuangan, dan juga pihak kampus kepada masyarakat. Karena pentingnya program ini, program peningkatan literasi harus bersifat masif dan kontinue pada masyarakat untuk memberantas ketidaktahuan akan instrumen keuangan. Dalam rangka peningkatan kapabilitas keuangan, konsep-konsep edukasi dan praktik yang memberikan akses pada pelayanan finansial dan institusinya diyakini dapat mendorong masyarakat memilih gaya hidup yang sesuai dengan tingkat literasinya (Jonson dan Sherraden, 2007). Krisis keuangan secara makro, berdampak pada kompleksitas keuangan rumahtangga. Meskipun Mendell \& Klein (2009) menunjukkan bahwa prilaku individu yang telah mendapatkan edukasi literasi keuangan tidak bersikap lebih saving-oriented dan tidak menunjukkan prilaku menggunakan finansial lebih baik daripada yang belum di edukasi. Namun lebih banyak studi menunjukkan bahwa literasi keuangan personal, literasi keuangan keluarga bermanfaat untuk membuat keputusan keuangan pada bidangnya (Perry, 2008; 
Hilgert et al., 2003; Mendel \& Klein, 2009).

McCormick (2009) menjelaskan dampak krisis keuangan secara khusus mempengaruhi kehidupan anak-anak dan kaum muda. Momen kegagalan finansial menjadi peluang para pihak melakukan edukasi melalui literasi keuangan personal dan keuangan rumahtangga agar dapat memperbaiki kemampuan pengelolaan keuangan pribadinya maupun rumahtangganya (McCormick, 2009; Baker \& Ricciardi, 2015). Hal yang menjadi perhatian literasi keuangan menurut Hogart (2006) termasuk (a) menjadi berwawasan, terdidik, dan memahami hal mengenai pengelolaan uang dan aset, memahami pentingnya bank, invrestasi, kredit, asuransi, dan pajakpajak. (b). Memahami konsep pengelolaan uang dan hartanya, (c) dapat menggunakan pengetahuan dan pemahamannya untuk merencanakan, mengimplementasi dan mengevaluasi keputusan-keputusan keuangannya.

\section{Manajemen Keuangan}

Manajemen keuangan pada keluarga mengacu pada proses yang secara bijak menganggarkan, membelanjakan, menyimpan dan menginvestasikan dana yang dihasilkan dari honor, gaji, dan sumber penerimaan lainnya. Pengelolaan dana yang baik sangat penting dalam sebuah keluarga. Manajemen keuangan dapat dikaitkan dengan pelaksanaan fungsifungsi manajemen seperti perencanaan, pengendalian keuangan. Beberapa kiat manajemen keuangan yang sehat menurut national resource center for healty marriage and families (Haris, 2014) yaitu pertama, mengidentifikasi sikap dan kebiasaan penggunaan dana sehari-hari. Kedua, membuat skala prioritas pengeluaran dan hidup hemat yang menyaratkan pengeluaran lebih kecil dari penerimaan. Ketiga, menelusuri dan mengurangi biaya saat menjalankan budget yang telah ditetapkan. Keempat, menghindari hutang sedapat mungkin dan mengelola pinjaman secara bijak. Pilih kartu kredit dengan bunga rendah jika perlu. Kelima, bangun kepercayaan dengan membayar cicilan secara reguler dan tepat waktu. Keenam, membuka akun/rekening tabungan untuk memudahkan dengan tidak perlu menyimpan dan membawa uang tunai di rumah, sehingga anda tidak perlu cemas akan kerampokan/kecurian. Ketujuh, hindari lintah darat. Kedelapan, sisihkan dana sebagai dana emergensi.

\section{Perencanaan Keuangan}

Perencanaan merupakan proses penetapan tujuan dari suatu organisasi, strategi pencapaian tujuan organisasi serta langkah-langkah teknis yang dilakukan sehingga tujuan organisasi tersebut dapat tercapai dengan efektif dan efisien (OJK, 2016). Perencanaan keuangan penting karena manusia hanya dapat merencanakan sedangkan segala sesuatu yang akan terjadi di masa datang tidak diketahui. Meskipun semua tidak akan berjalan selancar yang direncanakan, namun kegiatan yang terarah dengan adanya perencanaan akan lebih mungkin berjalan lebih baik daripada yang tidak ada perencanaan terlebih dahulu. Perencanaan keuangan tetap perlu dilakukan tanpa membedakan aktivitasnya tergolong besar ataupun kecil. Perbedaannya hanya pada dampaknya akan berskala besar ataupun kecil. Kesuksesan pengelolaan keuangan terletak pada keberhasilan dalam mengatur pengeluaran daripada pengaturan penerimaan. Pada perencanaan keuangan, perlu dibedakan makna kebutuhan dan keinginan (OJK,2016). Secara umum kebutuhan dasar terdiri atas: 
a. Kebutuhan fisik: makanan, pakaian, keamanan

b. Kebutuhan sosial: memiliki seseorang dan kasih sayang

c. Kebutuhan individual: pengetahuan dan kemampuan mengekspresikan diri.

Sedangkan keinginan merupakan pengembangan kebutuhan yang dibentuk oleh lingkungan, budaya dan pengalaman pribadi masing-masing individu. Semakin banyak informasi yang diserap maka semakin banyak pula keinginan muncul. Manusia mempunyai kebutuhan yang syaitu kebutuhan dasarnya akan tetapi mempunyai keinginan yang tidak terbatas (OJK, 2016). Oleh karena itu perlu diidentifikasi sesuatu yang tergolong kebutuhan dasar dan mana yang terklasifikasi sebagai keinginan.

Pada proses pembuatan perencanaan keuangan, perlu diidentifikasi kondisikondisi yang mungkin timbul dikemudian hari. Menurut Ilham Fahmi (2014), terdapat tiga kondisi yang harus diantisipasi dalam penyusunan perencanaan keuangan (Saerang \& Maramis, 2017) yaitu:

a. Kondisi buruk. Kondisi buruk dalam keluarga dapat dipengaruhi oleh berbagai sebab seperti krisis moneter, kekacauan ekonomi, kerusuhan dan faktor lingkungan lainnya sehingga perlu disusun asumsi sebagai tindakan antisipatif.

b. Kondisi normal. Pada kondisi ini rencana disusun dengan menggunakan asumsi dengan menggunakan prinsip kehatihatian.

c. Kondisi baik dan bertumbuh.

Perencanaan keuangan dapat dilakukan dengan tiga tahap (OJK, 2016) yaitu:

1. Tahap pertama, penentuan tujuan keuangan. Tujuan keuangan dapat disusun dengan membuat rumusan SMART yaitu: (a). Specific.
Pengunggapan tujuan harus memakai kata yang ringkas,lugas, spesifik, tidak bermakna ganda.(b). Measurable, hasil yang akan dicapai dapat diukur. (c). Attainable, meskipun tujuan keuangan tidak selalu hanya satu, sehingga haruslah dibuat skala prioritas yang dapat dicapai. (d) Realistic. Tujuan yang dicapai realistis sehingga dapat terhindar dari situasi keuangan yang buruk. (e). Timely. Jangkawaktunya jelas kapan tujuan keuangan harus dicapai.

2. Tahap kedua, memeriksa kondisi keuangan saat ini.

3. Tahap ketiga, mengumpulkan informasi data yang relevan.

Selain hal diatas, setidaknya terdapat lima pertimbangan yang dapat dipertimbangkan untuk membuat perencanaan keuangan keluarga yaitu: (1). Berinvestasi bukanlah tujuan. Walaupun Anda telah dapat menyisihkan uang untuk menabung dan berinvestasi dalam berbagai instrumen investasi, tanpa adanya tujuan keuangan, maka aset tersebut belum tentu dapat berfungsi secara maksimal. Penentuan aset akan lebih bisa jika disesuaikan dengan tujuan keuangan yang ingin dicapai kedepannya dalam jangka waktu dibawah 1 tahun, jangka waktu hingga 5 tahun, dan juga diatas 10 tahun lagi. (2). Mengatur prioritas pengeluaran. Banyak orang membeli barang atau kegiatan yang mahal, misalnya mobil, rumah atau paket liburan secara impulsif, saat merasa memiliki uang. Bisa jadi rumah tangga mendapatkan pemasukan besar dari bonus atau tunjangan lain. Sayangnya, kebutuhan lain yang lebih penting mungkin lupa untuk diprioritaskan. Kebutuhan manusia terdiri dari kebutuhan saat ini seperti biaya hidup rutin, bayar uang sekolah bulanan, dan lainnya. Di masa depan, juga perlu 
disediakan dana pendidikan yang biayanya terus naik melebihi inflasi. Selain itu dana pensiun yang perlu disiapkan secara seksama, dan dana kesehatan pensiun yang juga sangat penting. Rencana keuangan memiliki peran besar dalam hal bagaimana sebuah keluarga dapat mencapai tujuan keuangan tersebut. (3). Alokasi pengeluaran yang ideal. Pada umumnya, nilai pengeluaran setiap bulan tidak diketahui secara pasti alokasi penggunaannya di setiap pos pengeluaran. Padahal, memahami kemana saja penggunaan penghasilan rumah tangga merupakan kunci sukses dalam mencapai kehidupan yang lebih sejahtera. (4). Siklus hidup dan tujuan keuangan. Perencanaan keuangan juga akan memaksimalkan alokasi aset yang dimiliki. Untuk mengoptimalkan aset, ada rekomendasi yang berbeda sesuai dengan umur, tingkat risiko dan kebutuhan. Siklus hidup manusia dalam hal keuangan biasanya terbagi menjadi lulusan baru, pasangan baru, keluarga muda, keluarga dewasa, dan masa pensiun. Setiap tahapan kehidupan memiliki tantangan dan fokus tujuan keuangan yang berbeda. (5). Tepat menghitung proteksi finansial. Merencanakan keuangan bukan hanya berinvestasi, tetapi juga melindungi keluarga dengan proteksi yang sesuai. Sebagai orang tua, sebagian dari Anda mungkin ingin memastikan anak-anak tetap dapat mengenyam pendidikan baik hingga lulus tanpa khawatir ada hal tak terduga yang dapat menimpa orang tua. Oleh sebab itu, fungsi asuransi jiwa sebagai proteksi belum dapat digantikan. Dengan rencana keuangan, Anda akan dapat menghitung berapa kebutuhan uang pertanggungan yang dibutuhkan.

\section{Tujuan Kegiatan dan rencana pemecahan masalah}

Literasi keuangan melalui perencanaan keuangan keluarga menjadi penting di tengah masyarakat, termasuk masyarakat sekolah yang meliputi para guru, para murid, dan para pegawai sekolah. Individu tersebut merupakan bagian dari keluarganya masing-masing ditengah masyarakat. Individu pada sekolah SMK Dayun berdasarkan informasi yang diperoleh dan observasi lapangan juga mempunyai permasalahan keuangan. Selain disebabkan naiknya harga-harga barang konsumsi dan juga karena kebutuhan keluarga yang bertambah, sementara pendapatan gaji tidak berubah, maka kesulitan keuangan dirasakan meningkat. Beberapa guru, dan pegawai lainnya berupaya meningkatkan upaya dengan bekerja sampingan, sebagian lain justru terjerat dengan hutang. Banyak pegawai yang menerima gaji pada awal bulan hanya separuh dari gaji bulanan. Hal ini karena adanya potongan gaji yang berasala dari angsuran hutang akibat kejadian sebelumnya. Apabila terjadi hal-hal yang tidak diduga, seperti sakit, musibah dan sebagainya, maka kondisi ini akan menjadi semakin rumit.

Dari observasi lapangan dan penjelasan di atas dapat kami ringkas permasalah mitra yang terjadi terkait dengan perencanaan keuangan keluarga adalah sebagai berikut:

1. Lazimnya pola kebiasaan prilaku konsumtif pada keluarga karena tuntutan gaya hidup.

2. Bagaiman anggota keluarga dapat merasakan pentingnya menyususn skala prioritas dalam pengeluaran biaya.

3. Tingkat literasi keuangan masyarakat yang rendah. 
4. Dalam menjalankan hidup seharihari belum didasarkan pada perencanaan keuangan keluarga.

Proposal pengabdian ini kemudian bertujuan untuk memberikan pemahaman kepada masyarakat tentang literasi keuangan melalui perencanaan keuangan keluarga sebagai instrument penting bagi pengelolaan keuangan keluarga untuk memperbaiki menuju keluarga sejahtera.

Kegiatan pengabdian ini bertujuan untuk: (1) meningkatkan kesadaran masyarakat sekolah tentang pentingnya perencanaan keuangan, (2) memberikan pengetahuan tentang pentingnya pemahaman edukasi pengelolaa keuangan, (3) memberikan pemahaman tentang pergeseran prilaku ke hidup hemat bukan sebaliknya hidup boros dengan menekankan pada apa yang dibutuhkan dalam hidup bukan apa yang diinginkan saja, dan (4) memberikan pelatihan dan penyuluhan tentang literasi keuangan melalui perencanaan keuangan.

Adapun solusi yang ditawarkan untuk pemecahan masalah tersebut adalah melalui program Ipteks bagi masyarakat dengan kegiatan workshop dan pelatihan kepada masyarakat sekolah bagaimana merencanakan, mengelola keuangan keluarga secara efektif dan efisien yang meningkatkan kesejahteraan keluarga.

\section{METODE PENGABDIAN Materi dan Pelaksana}

Merujuk pada hasil observasi lapangan dan diskusi kepada beberapa peserta tersebut, masih terdapat beberapa permasalahan menyangkut perencanaan keuangan individu, perlunya peningkatan literasi keuangan, adanya prilaku dan gaya hidup yang cenderung konsumtif, perlunya peningkatan wawasan mengenai produk-produk industri keuangan dan sebagainya. Materi yang diberikan dalam pengabdian ini adalah terkait dengan perencanaan keuangan keluarga, pelatihan praktis dengan contoh-contoh sehari-hari, pengenalan manajemen keuangan, mengedukasi masyarakat untuk meningkatkan pemahaman produk industri keuangan, memberikan motivasi dan himbauan untuk mengubah tendensi prilaku konsumtif menjadi investatif.

Kegiatan pengabdian masyarakat ini dilakukan oleh Dosen Program Studi Akuntansi Fakultas Ekonomi dan Bisnis. Adapun peran mitra adalah memfasilitasi informasi yang cukup dan menyediakan data-data yang mendukung terkait dengan permasalahan riil yang terjadi pada kehidupan sehari-hari para guru di sekolah SMK.

Kegiatan pengabdian masyarakat tentang peningkatan literasi keuangan melalui pengelolaan keuangan keluarga yang dilakukan bertempat di Dayun Kabupaten Siak Sri Inderapura pada hari Kamis tanggal 15 Maret 2018.

\section{Ruang Lingkup dan Objek Pengabdian}

Objek yang menjadi sasaran dari kegiatan pengabdian ini adalah para guru sekolah, para pegawai sekolah seperti tenaga administrasi, tenaga kebersihan, tenaga keamanan, dan termasuk siswa sekolah di SMK di Dayun Kecamatan Dayun. Mereka yang menjadi sasaran adalah seluruh masyarakat sekolah pada SMK Dayun Kecamatan Dayun.

\section{Metode Pengabdian}

Kegiatan pengabdian ini dilakukan dengan menggunakan pendekatan pelatihan dan penyuluhan pengurus guru-guru, seluruh pegawai sekolah, dan juga siswa sekolah. Adapun langkah-langkah yang dilakukan yaitu: (1) tahap meningkatkan pengetahuan individu mengenai perencanaan 
keuangan, meningkatkan pemahaman mengenai produk-produk pada industri keuangan, memberikan motivasi untuk pengembangan individu dan perubahan prilaku (2) pada tahap perencanaan, mengajak individu untuk mengidentifikasi kebutuhan sehari-hari dan mengidentifikasi skal prioritas, mengidentifikasi sumber-sumber penghasilan, membuat rencana anggaran, membuat realisasi anggaran, membuat evaluasi dan penyesuaian secara berkala, dan merencanakan keuangan jangka panjang (3) pada tahap implementasi, setiap individu dibimbing untuk menyusun dash board keuangan sehari-hari.

\section{HASIL DAN PEMBAHASAN}

Aktivitas pengabdian masyarakat ini dimulai dengan persiapan pelaksaan kegiatan, yaitu persiapan tim dengan melakukan rapat koordinasi, pembuatan surat menyurat, dan kegiatan pelatihan dan penyuluhan bagi masyarakat sekolah.

Pada tahap selanjutnya adalah persiapan kelengkapan kegiatan yang meliputi hal-hal sebagai berikut: (a). Mempersiapkan tempat pelaksanaan pelatihan dan penyuluhan, yaitu ruang kelas sekolah yang di sediakan pihak Sekolah. (b). Mempersipkan media presentasi, yaitu slide presentasi dan Infocus/LCD. (c). Pembuatan modul yang akan digunakan dalam workshop dan pelatihan. Modul tersebut dibuat oleh pemateri dengan cakupan berupa materi-materi yang akan diberikan dalam pelatihan. Modul tersebut dibuat dalam bentuk tutorial, teori dan contoh format kertas kerja.

Dalam kegiatan pelatihan tersebut, terdapat dua kelompok pemateri, kelompok pertama yaitu pemateri yang menjelaskan tentang pentingnya perencanaan keuangan, pengenalain produk industri keuangan. Pada tahap ini, pemateri didampingi oleh asisten yang mendukung terciptanya suasana interaktif antara audiens dengan pemateri. Aktivitas pendampingan telah dimulai pada tahap ini. Pada materi kedua, peserta diminta untuk menyusun rencana keuangan dengan mengidentifikasi sumber pendapatan dan jenis pengeluaran. Peserta diberikan pendampingan langsung untuk menyusun rencana konkrit pada keuangan keluarnya.

Workshop dan pelatihan diberikan selama lebih kurang 4 jam dan kemudian dilanjutkan dengan diskusi antara peserta dengan pemateri. Pada sesi diskusi, para peserta terlihat sangat antusias dengan menyampaikan pertanyaan-pertanyaan terkait dengan permasahan yang selama ini mereka hadapi di praktiknya. Banyak peserta yang menyampaikan saran kepada panitia agar kegiatan seperti terus dilakukan dalam rangka untuk meningkatkan pemahaman pengelolaan keuangan termasuk peningkatan pemahaman mengenai produk indutsri keuangan seperti asuransi, perbankan syariah, dan investasi syariah. Pada akhir kegiatan, para peserta dan panitia berfoto bersama untuk mengabadikan kegiatan yang dilakukan serta diakhiri dengan makan bersama.

\section{KESIMPULAN DAN SARAN}

$\begin{array}{lr}\text { Kesimpulan dari } & \text { kegiatan } \\ \text { pengabdian } & \text { masyarakat } \\ \text { masyarakat sekolah SMK } & \text { Dayun }\end{array}$ Kecamatan Dayun Kabupaten Siak untuk program peningkatan literasi keuangan melalui perencanaan keuangan keluarga adalah sebagai berikut: (a). Peserta pelatihan sangat antusias ketika mengikuti pelatihan dan penyuluhan. Para peserta dapat melihat manfaat pelatihan ini, yakni menambah pengetahuan pada bidang manajemen pengelolaan keuangan keluarga, 
khususnya pada personel sekolah yang tentunya merupakan bagian dari keluarganya masing-masing di masyarakat. (b). Berdasarkan sharing yang dilaksanakan pada saat diskusi, tidak ada kesan buruk dari peserta selama pelaksanaan workshop, baik dari segi sarana dan prasarana maupun penyampaian materi, hanya saja perlu dibuat dalam skala yang lebih luas. (c). Perserta dapat membedakan kebutuhan dengan keinginan dengan menggunakan skala prioritas yang disusun. Demikian juga dengan membentuk kebiasaan dari "jika bisa membeli, kenapa harus membuat, menjadi jika bisa membuat kenapa harus membeli" pada konteks keluarga yang masih sangat mungkin untuk mengaplikasikannya.

Pengabdian selanjutnya tetap diarahkan pada sharing masalah keuangan dan pengembangan pengenalan pada produk industri keuangan yang diperlukan dalam kehidupan sehari-hari seperti asuransi kesehatan, asuransi kerugian, investasi produk syariah, perbankan syariah dan sebagainya. Oleh karena itu, pengembangan pengabdian selajutnya kemungkinan akan diarahkan pada pelatihan manajemen keuangan yang terkait dengan keuangan syariah, investasi syariah, dan asuransi. Pengabdian selanjutnya ada diarahkan kepada pengenalan aspek syariah pada keuangan Tempat kegiatan pengabdian disarankan menyasar daerah-daerah yang masih tertinggal dan belum memahami tentang perencanaan keuangan kelarga yang baik dan benar.

\section{DAFTAR PUSTAKA}

1. Baker, H.K., \& Ricciardi, V., (2015). Understanding behavioral aspects of financial planning and investing, Journal of financial Planning.
2. Haris, V. (2014). Tips for service healty financial management skills, Fairfax. National Resources center for healty marriage and families, Available at: http://tinurl.com/tipsfor-providers-fm- $p$

3. Hilgert, M.A., Hogart, J.M., \& Berly, S.G., (2003). Household financial management: the connection between knowledge and behavior, Federal reserve Bulletin, 89, 309-322.

4. Johnson, E., \& Sheraden, M., (2007). From financial literacy to financial capability among youth, Journal of sociology and social welfare, 34 (3), 119-146

5. McCormick, M.H., (2009). The effectiveness of youth financial education: a review of the literature, Journal of financial counceling and planning, Vol. 20 issue 1.

6. Mendel, K., \& Klein, L.S. (2009). The impact of financial literacy education on subsequent financial behavior, Journal of financial counceling and planning, Vol. 20 issue 1

7. Nainggolan, Pahala. (2012). "Manajemen Keuangan Lembaga Nirlaba”. Yayasan Bina Integrasi Edukasi (YBIE).

8. Perry, V.G. (2008). Is ignorance bliss? Consumer accuracy in judgement about credit rating, The Journal of consumer affair, 42 (2), 189-202.

9. Otoritas Jasa Keuangan, (2016). Perencanaan Keuangan, Seri Literasi Keuangan Perguruan Tinggi, Penerbit Otoritas Jasa Keuangan, Jakarta

10.Saerang, I.S., \& Maramis, J.B. (2017). Eksplorasi respon perencanaan dan pengelolaan keuangan keluarga, Jurnal manajemen bisnis dan inovasi, Vol. 4 No.2 hal. 110-115. 